disorders on the approved list, despite there being no regulation to that effect.

This list can serve only as a guide. Though quite useful in diabetic wounds, hyperbaric oxygen is only part of a programme of total wound care. For some diabetic wounds hyperbaric oxygen is inappropriate if the large vessels distal to the trifurcation at the knee are occluded or severely stenotic. Crush injury and impending compartment syndrome need to be treated immediately if any worthwhile result is to follow. Late referral, which gives time for oedema, reperfusion, and injury; free radical damage; and the no reflow phenomenon to do their work, makes the treatment largely a waste of time and money. For some surgical patients the potential dangers of further trauma to the wound during transportation will militate against the use of hyperbaric oxygen. Experience has shown, however, that patients with severe carbon monoxide poisoning can be transported safely over long distances in a properly equipped ambulance or helicopter.

Before transfer of a critically ill patient is contemplated it should be ascertained that the receiving chamber facility can deliver the necessary level of intensive care. Whenever the use of hyperbaric oxygen is considered, consultation with the physician in charge of the hyperbaric oxygen facility is mandatory to ensure that referral is appropriate. The timing of hyperbaric oxygen in relation to surgery is also critically important. For example, in necrotising fasciitis, surgery is the accepted primary treatment, with hyperbaric oxygen used as a follow up. With gas gangrene, however, the hyperbaric chamber is used before surgery (other than for fasciotomy). In the treatment of radionecrosis the patient should be treated at least 20 to 30 times in the chamber, to induce the formation of new capillaries, before elective surgery is performed if healing is to be expected.

ERIC P KINDWALL Director of hyperbaric medicine

Departments of Plastic and Reconstructive Surgery

and Pharmacology and Toxicology,

Medical College of Wisconsin,

Milwaukee,

Wisconsin 53226

United States
1 BMA Board of Science and Education. Clinical hyperbaric medicine facilities in the UK. London: BMA, 1993.

2 Perrins DJD, Maudsley RH, Colwill MR, Slack WK, Thomas DA. OHP in the management of chronic osteomyelitis. In: Brown IW, Cox BG, eds. Proceedings of the third international conference on hyperbaric medicine. Washington, DC: National Academy of Sciences, National Research Council, 1966:578-89. (Publication 1404.)

3 Thom SR. Antagonism of carbon monoxide-mediated brain lipid peroxidation by hyperbaric oxygen. Toxicol Appl Pharmacol 1990;105:340-4.

4 Nylander G, Lewis D, Nordstrom H, Larsson J. Metabolic effects of hyperbaric oxygen in post-ischemic muscle. Plast Reconstr Surg 1987;79:91-6.

5 Cianci P, Lueders HW, Lee H, Shapiro RL, Sexton J, Williams C, et al. Adjunctive hyperbaric oxygen therapy reduced length of hospitalisation in thermal burns. $f$ Burn Care Rehabil 1989;19:432-5.

6 Nylander G, Nordstrom H, Eriksson E. Effects of hyperbaric oxygen on oedema formation after a scald burn. Bums 1984;10:193-6.

7 Stewart RJ, Yamaguchi YT, Cianci PA, Knost PM, Samadani S, Mason SW et al. The effects of hyperbaric oxygen on adenosine triphosphate in thermally injured skin. Surgical Forum 1988;39:87-90.

8 Wells $\mathrm{CH}$, Hinton JG. Effects of hyperbaric oxygen on post-burn plasma extravasation. In: Davis JC, Hunt TK (eds). Hyperbaric oxygen therapy. Bethesda, Maryland: Undersea Medical Society, 1977:259-65.

9 Zamboni WA, Roth AC, Russell RC, Graham B, Suchy H, Kucan JO. Morphological analysis of the microcirculation during reperfusion of ischemic skeletal muscle and the effect of hyperbaric oxygen. Plast Reconstr Surg 1993;91:1110-23.

10 Mathieu D, Coget J, Vinckier F, Saulnier A, Durocher ET, Wattel F. Red blood cell deformability and hyperbaric oxygen. Med Subaquatique Hyperbar 1984;3:100-4.

11 Mader JT, Brown GL, Gluckian JC, Wells CH, Reinarz JA. A mechanism for the amelioration by hyperbaric oxygen of experimental staphylococcal osteomyelitis in rabbits. $f$ Infect Dis 1980;142:915-22.

12 Davis JC, Heckman JD, DeLee JC, Buckwold FJ. Chronic non-hematogenous osteomyelitis treated with adjuvant hyperbaric oxygen. I Bone foint Surg $[A m]$ 1986;68:1210-7.

13 Riseman JA, Zamboni WA, Curtis A, Graham DR, Konrad HR, Ross DS. Hyperbaric oxygen therapy for necrotising fasciitis reduced mortality and the need for debridements. Surgery 1990;108:847-50.

14 Marx RE, Johnson RP. Problem wounds in oral and maxillofacial surgery: the role of hyperbaric oxygen. In: Davis JC, Hunt TK, eds. Problem wounds: the role of oxygen. New York: Elsevier Science Publishing, 1988:65-125

15 Marx RE, Johnson RP, Kline SN. Prevention of osteoradionecrosis: a randomised prospective clinical trial of hyperbaric oxygen versus penicillin. $₹$ Am Dent Assoc 1985;111:490-554.

16 Kaelin CM, Im MJ, Myers RA, Manson PN, Hoopes JE. The effects of hyperbaric oxygen on free flaps in rats. Arch Surg 1990;125:607-9.

17 Manson PN, Anthenelli RN, Im MJ, Bulkley GB, Hoopes JE. The role of oxygen-free radicals in ischemic tissue injury in island skin flaps. Ann Surg 1983;198:87-90.

18 Daris IC Hyperbaric oxyen therapy. Intensive Care Med 1989;4:55-7.

19 Goulon M, Barois A, Rapin M, Nouailhat F, Grosbuis S, LaBrousse J. Intoxication oxycarbonee et anoxie aigue par inhalation de gaz de charbon et hydrocarbures. Ann Intern Med 1969;120: anoxie a. $335-49$.

20 Hart GB, Lamb RC, Strauss MB. Gas gangrene 1: a collective review. I Trauma 1983;23:991-5.

21 Kindwall EP. Uses of hyperbaric oxygen therapy in the 1990s. Cleve Clin 7 Med 1992;59:517-28.

22 Strauss MB, Hargens AR, Gershuni DH, Greenberg DA, Crenshaw AG, Hart GB, et al. Reduction of skeletal muscle necrosis using intermittent hyperbaric oxygen in a model compartment syndrome. 7 Bone foint Surg [Am] 1983;65:656-62.

23 Thom SR. Hyperbaric oxygen therapy: a committee report. Bethesda: Undersea Hyperbaric and Medical Society, 1992.

\title{
Primary care and public health
}

\section{Too far apart}

In Britain primary care and public health have their roots in the early nineteenth century: general practitioners evolved from surgeon-apothecaries, and the public health movement emerged in response to the problems of urbanisation. Divergent for so long, their paths should be coming closer together.

Personal preventive services, such as immunisation and family planning, were made the responsibility of medical officers of health in 1919, ${ }^{1}$ but item of service fees under the NHS encouraged general practitioners to provide such services. In 1990 general practitioners were made responsible for health promotion and disease prevention for the first time. Their objections to the new contract were not so much because of this extension of general medical services, but because it rewarded them for doing things for which there was little or no scientific support. ${ }^{2}$ At the time there was little response from public health medicine, but three years later health promotion is being rethought.

In 1974 the Faculty of Community Medicine emphasised a management role that excluded those with clinical responsibilities. At the same time medical officers of health were replaced by medical officers who were advisers rather than advocates for the public health. However, it was not found necessary to rely on community medicine specialists for top management positions in the Griffiths reorganisation, ${ }^{3}$ and it seemed that the speciality had lost its way. The response was the Acheson report of 1988, ${ }^{4}$ which recommended a change of name to public health medicine. Its role was to set targets, allocate resources, evaluate progress, control communicable diseases, and promote health. Directors of public health were meant to be the main source of medical advice for health authorities.

There is now role confusion in both branches of the profession. Some of the administrative complexities of the new general practice contract, intended to increase competition, have had the unintended effect of making general practitioners wonder if they would not be better off as a salaried service. Many are ambivalent about health 
promotion driven by financial inducements and concerned about the emergence of a two tier system of care.

Public health medicine is unsure of its role in the new world of purchasers and providers. ${ }^{56}$ As a profession it argues for more specialists ${ }^{7}$ despite the likelihood of further mergers between health authorities but is anxious about seeking links with other groups such as environmental health. ${ }^{8}$ Above all, the two branches of the profession have pursued different career pathways, with general practitioners having had little training in the skills of population medicine and public health doctors hardly noticing that another group is now formally responsible for promoting health and preventing disease. A recent report by the Faculty of Public Medicine on health in Britain seems to ignore general practice altogether. ${ }^{9}$ With the two branches of the profession talking past each other, managers have increasingly set the agenda for the NHS.

The challenge for general practitioners and public health doctors is to define their core values and identify where these values conflict with prevailing market or political forces. This recognition lay behind the independence of medical officers of health and the independent contractor status of general practitioners. This allowed the two branches of the profession to act as advocates for the health of the public and individual patients. The health service reforms provide an opportunity for primary care and public health to reassert the values of a common profession. The barriers between the specialties need to be broken down by joint appointments so that epidemiology and health promotion are given credibility by clinical contact. The divergent career pathways of general practice and public health medicine need to have more links. This is beginning to happen with postgraduate masters courses for general practitioners and the appointment of specialists in public health medicine to family health services authorities.

General practitioners and public health doctors are both responsible for preventing disease and promoting health. Both are involved in purchasing, and both belong to an independent profession, which means accountability to their patients and the public rather than the political expediency of market places. Primary medical care needs to develop within the broader context of primary health care, which requires a reconciliation between the medical care of individual patients and the health of populations. The new emphasis on health promotion provides general practitioners and public health doctors with an opportunity to rediscover their common roots and core values.

DAVID R HANNAY Professor

Department of General Practice,

Medical School,

Sheffield S10 2RX

1 Ministry of Health Act 1919. London: HMSO, 1919.

2 Morrell DC. Role of research in development of organisation and structure of general practice. $B M \mathcal{F}$ 1991;302:1313-6.

3 Griffiths R. Report of NHS management inquiry. London: DHSS, 1983.

4 Committee of Inquiry into the Future Development of the Public Health Function. Public health in England. London: HMSO, 1988.

5 Whitby $\mathrm{P}$, Jones I. Public health heresy: a challenge to the purchasing orthodoxy. $B M \mathcal{F}$ 1992;304:1039-41.

6 Bhopal RS. Public health medicine and purchasing health care. $B M 7$ 1993;306:381-2.

7 Todd J. The public health function. Public Health Physician 1992;3(2):4.

8 Griffiths R. The need for boundaries. Public Health Physician 1992;3(4):1.
National human pituitary programmes supplying human growth hormone and human pituitary gonadotrophins were established in the 1960s after evidence that pituitary dwarfism could be treated with human growth hormone and anovulatory infertility with human pituitary gonadotrophin. The human pituitary programmes of most countries were ended abruptly in 1985 after reports of Creutzfeldt-Jakob disease in patients who had been treated with pituitary human growth hormone. ${ }^{1}$ To date around the world 28 cases of the disease have been reported in patients who received injections of human growth hormone derived from pituitary glands collected at necropsy. ${ }^{2}$

Creutzfeldt-Jakob disease was first described in 1920 as a rare cause of rapidly progressive dementia. The associated clinical features include ataxia, myoclonic movements of the limbs, and blindness. It is a sporadic disease with an incidence of one case per million population. Case reports have documented the disease not only after treatment with human growth hormone but also after neurosurgical procedures and corneal transplantation. ${ }^{3}$ Creutzfeldt-Jakob disease typically develops in people aged 50 to 75 , though it has occurred in teenagers after treatment with human growth hormone in childhood. It is undetectable in asymptomatic patients, in whom, apparently, it may incubate for up to 20 years. If symptoms develop there is no treatment, and the disease is uniformly fatal. Creutzfeldt-Jakob disease is related to other human spongiform encephalopathies such as kuru and the Gerstmann-Straussler syndrome.

The nature of the transmissible agent that causes the spongiform encephalopathies is still not fully elucidated; it is generally considered not to be a virus, and the name prion has been suggested. ${ }^{45}$ Prion protein is a membrane glycoprotein present in most organs including neurones and accumulation of this abnormal protein is central to the causation of the spongiform encephalopathies.

Recently, Collinge and colleagues screened the prion protein gene of seven patients who had developed CreutzfeldtJakob disease after treatment with growth hormone and found that four had an uncommon valine/valine 129 homozygous genotype, whereas in a control group of 106 healthy people they found only 13 with this genotype. This suggests that the presence of the 129 valine homozygosity may confer susceptibility to infection with exogenous prion. ${ }^{6}$ The study awaits confirmation but suggests a possible screening procedure for susceptibility to Creutzfeldt-Jakob disease among patients previously treated with hormones derived from human pituitary glands.

Against this background four women in or from Australia have developed Creutzfeldt-Jakob disease after treatment with human pituitary gonadotrophins-the first cases of Creutzfeldt-Jakob disease after gonadotrophin treatment. The first was a woman aged 40 living in Adelaide who had been treated in 1974 and $1975 .^{7}$ The diagnosis in the second case was serendipitous. The neurology registrar concerned with the first patient travelled to Britain for further postgraduate experience. On his arrival his consultant remarked that an Australian patient with Creutzfeldt-Jakob disease had recently been admitted and asked if he would care to see her. A history emerged of treatment with human pituitary 